https://helda.helsinki.fi

\title{
Management in relation to disturbance in the boreal forest
}

\section{Niemelä, J.}

Elsevier Science B.V.

1999

Niemelä, J. 1999. Management in relation to disturbance in the boreal forest. Forest Ecology and Management 115: 127-134.

http://hdl.handle.net/1975/214

Downloaded from Helda, University of Helsinki institutional repository.

This is an electronic reprint of the original article.

This reprint may differ from the original in pagination and typographic detail.

Please cite the original version. 


\title{
Management in relation to disturbance in the boreal forest
}

\author{
Jari Niemelä ${ }^{1}$ \\ Department of Ecology and Systematics, P.O. Box 17, FIN-00014, University of Helsinki, Finland
}

\begin{abstract}
Disturbances and the consequent habitat heterogeneity are natural features of the boreal forest. Natural disturbances occurring at the level of populations, communities and ecosystems (meters to kilometers and years to hundreds of years), that is, at the 'meso-scale' may provide useful guidelines for forest management. This approach is based on the assumption that species are adapted to the disturbance regime of the forest-type that they occupy. However, natural disturbance and human-caused disturbance, such as clear-cutting, may differ substantially in their ecological effects. Potential differences occur on several scales. On the stand scale, removal or destruction of important habitat structures, such as coarse woody debris, during traditional clear-cutting may affect species. On the landscape scale, fragmentation may cause local extinctions and hamper the recolonization of maturing sites by old-growth specialists. The effect of these differences on boreal biota needs to be assessed. On the stand scale, the degree of recovery (resilience) of populations and communities after human-caused disturbance versus natural disturbance, that is, the succession process, could be a useful criterion when developing new forestry methods. On the landscape scale, it is important to maintain enough patches of suitable habitat for the old-growth species in order to prevent local extinctions and to promote recolonizations. Natural landscapes could be used as a reference here. In conclusion, although possibilities of matching forestry with maintenance of taiga biota through development of harvesting methods that mimic natural disturbance seem reasonably good, there is an urgent need to establish criteria for the assessment of the success or failure of such methods. The resilience of forest ecosystems as reflected in population changes of surrogate taxa after disturbance could be used to guide management. (C) 1999 Elsevier Science B.V. All rights reserved.
\end{abstract}

Keywords: Boreal forest; Disturbance; Management; Biodiversity

\section{Introduction}

During recent years a paradigm shift has taken place in ecology and conservation (Haila, 1995). Change and dynamism have replaced equilibrium and 'balance of nature' as the prevalent approaches to land-use management (Pimm, 1991; Wu and Loucks, 1995). In forestry, this paradigm shift has initiated development of new harvesting practices that use the natural

\footnotetext{
${ }^{1}$ Tel.: +358-9-1917391; fax: +358-9-1917492; e-mail: jari.niemela@helsinki.fi
}

or primordial forest dynamics as a guideline (Hansen et al., 1991; Hunter, 1993; Niemelä, 1997).

The approach of mimicking natural disturbance is believed to better ensure sustainable use of forest resources, although little is known about the ecological basis of this approach (Noss and Cooperrider, 1994). For instance, it may be difficult to establish the 'natural' type of vegetation that should be the goal for management and the kind of 'natural' disturbance that should be mimicked (Sprugel, 1991; Haila, 1995, 1997). Furthermore, an exact match between a natural disturbance regime and forestry operations is unattain- 
able, as the basic idea of forestry is to remove timber from the forest (Haila et al., 1994). Thus, if disturbance dynamics are to be used to guide management decisions, understanding of the relationships between natural and human-caused disturbances is crucial.

It is obvious that forestry has already brought about changes in the silviculturally managed boreal forests on various ecological scales (Esseen et al., 1997). On the small scale, particular microhabitats, such as coarse woody debris, have diminished. On the stand and landscape levels forest fire has been replaced by logging as the main disturbance initiating secondary succession. Furthermore, the spatio-temporal dynamics created by forestry, such as arrangement and size of patches of mature forest, differ from that in the fire-originated landscape (Haila et al., 1994; Syrjänen et al., 1994; Edenius and Elmberg, 1996; Wallin et al., 1996). With this gloomy background the goal of new, ecologically sound forestry should be to prevent further losses and, if possible, to restore populations of declining species. The colonization of species from large, unmanaged forest tracts to the ones being restored may still be possible in many parts of the boreal forest. For instance, several species threatened or extinct in Finland have viable populations in the adjacent Russian boreal forests (Siitonen and Martikainen, 1994).

The aim of this paper is to discuss the use of natural disturbance regimes to guide management of boreal forest. Furthermore, I will present some ideas about the methods and approaches of assessing the recovery and community change after disturbance. I will focus on the Fennoscandian boreal forests, but most likely the approach is applicable in other parts of the taiga as well because of similarities of species responses to logging in the Palaearctic and in the Nearctic (Niemelä et al., 1994).

\section{Natural disturbance and forest management}

\subsection{From 'balance of nature' to disturbance dynamics}

The old paradigm in ecology was concerned with the 'balance of nature', whereas the contemporary (or new) paradigm views ecosystems as dynamic and nonequilibrial (Wu and Loucks, 1995; Fiedler et al.,
1997). The new view arose for a number of reasons. An important one was that natural ecosystems were found to show multiple pathways of vegetation change and to have multiple persistent states often without a common local climax state (Holling, 1996). Furthermore, natural disturbances were found to be important in affecting species assemblages and succession pathways (Pickett et al., 1992; Perry and Amaranthus, 1997). From the role of natural disturbances there is a short, logical step to consideration of the effects of human-caused disturbances on ecosystems. Thus, the contemporary paradigm also permits the inclusion of human activities in the scope of ecology (Christensen et al., 1996).

The current biodiversity 'discourse' is a reflection of the contemporary non-equilibrium paradigm in ecology. The term 'biodiversity' refers to the overall heterogeneity in nature as a necessary property of ecological systems (Haila and Kouki, 1994). In order to maintain biodiversity processes producing diversity must be secured, and vice versa, biodiversity can buffer the ecosystem against unexpected perturbations. Thus, the patterns of biodiversity and the underlying processes are intimately linked.

As both the biodiversity 'discourse' and the new ecological paradigm emphasize the dynamism and heterogeneity of natural systems, resistance and resilience (recovery) become important ecosystem properties (Fiedler et al., 1997). 'Resistance' is defined here as the ability of the system to absorb perturbations and prevent them from amplifying into large disturbances, while 'resilience' is the capacity of the system to return to a given state after a disturbance (Perry and Amaranthus, 1997). Consequently, a relevant question in terms of forest management is how well and how rapidly ecosystems recover from the disturbance caused by timber harvesting.

\subsection{Disturbances and their spatio-temporal scales in the boreal forest}

Succession - a directed change in the ecosystem initiated by disturbance - is a process that maintains diversity. According to Angelstam (1996), there are five natural disturbance-types that initiate secondary succession in the boreal forest. Forest fire is the most important one, whereas storm fellings, snow, gap phase dynamics and browsing are less significant. A 


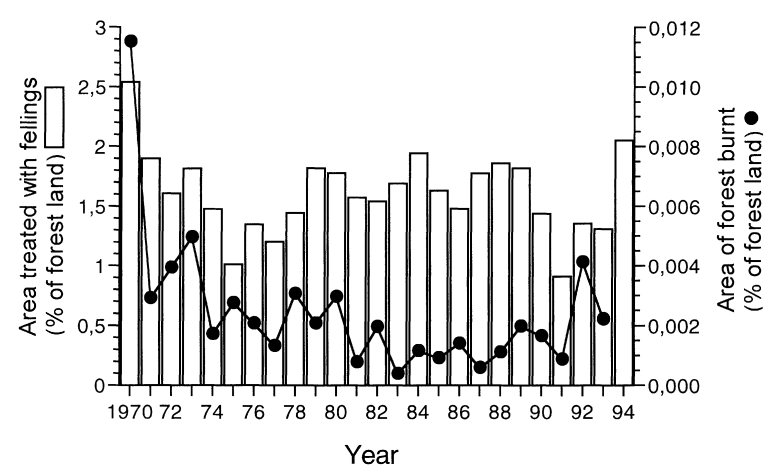

Fig. 1. Proportion of forest land treated with fellings (bars, scale at left) and burnt (black dots, scale at left) in Finland in 1970-1994. Source: Aarne (1995).

useful distinction between these disturbances is the spatial and temporal scale on which they operate. In primordial times, large fires (and in some cases storm fellings) may have covered thousands of hectares, whereas other disturbances cover smaller areas. An important characteristic of wild fire that has consequences for forestry is its temporal frequency in relation to topography and forest-type. Dry, pinedominated forests burn often (30-50 years intervals), whereas mesic and moist sites burnt less frequently (intervals $>160$ years), and on wet soils fire is virtually absent (Angelstam, 1996; Esseen et al., 1997).

Today forestry is the main disturbance in the Fennoscandian boreal forest, and forest fires have virtually disappeared (Fig. 1). A similar change has occurred in North America (Loope, 1991). Interestingly, in Fennoscandia, annually forest fires used to affect about the same proportion of forest land as does timber harvesting today (1-3\%, Esseen et al., 1997).

In the boreal forest - as in many other ecosystems there is a positive relationship between spatial and temporal scales of events. Phenomena that take place on a small spatial scale also cover a short timespan and events covering vast areas are slower (Urban et al., 1987; Holling, 1992) (Fig. 2). For instance, the growth and death of individual needles in a spruce is a smallscale event, while the cycles of Ice Ages are an example of a long-term event covering huge areas. Although forestry practices affect the well-being of an individual needle in a tree and climate changes affect vegetation in large areas, they are outside the operational spatio-temporal range of forestry practices which is the 'meso-scale' between the two extremes



Fig. 2. The relationship between spatial and temporal scales in the boreal forest (modified after Holling, 1992). The dashed circle indicates the 'meso-scale' in which forestry operates.

(Wiens, 1997) (Fig. 2). The natural disturbances taking place in the 'meso-scale' cover areas from a few square meters (death of single trees) to thousands of hectares (forest fire or large storm fellings), and temporal span from a few years (decaying of a log) to hundreds of years (regeneration and succession of boreal forest) (see also Urban et al., 1987).

\section{Disturbance guiding management}

\subsection{Management in relation to natural disturbance}

As a consequence of its intensity, forestry has already caused species declines in Fennoscandia. For instance, in Finland 43\% of the ca. 1700 endangered species are primarily threatened with forestry (Rassi et al., 1991). This species decline implies that forestry operations differ from natural disturbances in some fundamental ways. A relevant question then is how does disturbance caused by timber harvesting differ from natural disturbance? There are several important differences (Hansen et al., 1991; Hunter, 1993; Haila et al., 1994; Esseen et al., 1997). First, the periodicity of timber harvesting is often shorter than that of natural disturbance. A consequence of the short rotation time of forestry is that forest characteristics and structures typical for biologically old forests do not have enough time to develop (Wallin et al., 1996). Second, the spatial configuration of natural disturbance and logging are different. For instance, forest 
fire may cover large areas but within the affected area there may be patches that have burnt only partially or have remained intact (Syrjänen et al., 1994). Thus, forest fires, as well as windstorms, usually create a different kind of heterogeneity than does timber harvesting. Third, more residual organic matter is left after a natural disturbance. This is evident in the case of storm fellings, but also a forest fire may leave a considerable amount of partly burnt trees (Hansen et al., 1991). Fourth, charred wood is a required habitat for many species (Esseen et al., 1997). For instance, Wikars (1992) reported 34 pyrophilous insect species from Sweden. Fifth, harvested sites have often been regenerated using different tree species than the original ones. Especially conifers have been favoured at the expense of deciduous species. The consequence has been that deciduous species have become rare and the associated communities threatened (Esseen et al., 1997). In summary, forestry affects the landscape in several ways that appear to differ from the consequences of natural disturbances. In addition to diminishing area of old-growth forest, naturally initiated succession is a threatened process. Especially species requiring the early stages of fire-initiated successional stages are at risk (Wikars, 1992).

In order to correct the mismatch between natural and human-caused disturbance timber harvesting methods mimicking the spatio-temporal effects of natural disturbances have been developed during the recent years on two spatial scales (Hansen et al., 1991; Esseen et al., 1997). On the stand scale, the aim is to leave more trees (both dead and alive) in the cutblocks, and on the regional scale, landscape planning has been developed to create natural-like mosaics of different aged forest stands. For instance, the Finnish Forest and Park Service has published guidelines of landscape-level ecological harvesting planning (Hallman et al., 1996).

One of the recent approaches at the stand level is the ASIO-model (Angelstam et al., 1993) based on the logic that frequency of natural disturbance (i.e. fire) varies according to forest-type, and organisms dwelling in these forests are adapted to the natural disturbance regime. It then follows that species associated with a certain forest-type could cope more easily with the harvesting-caused disturbance, if it resembled the natural disturbance regime in that particular foresttype. In other words, the ecosystem would be more resilient and recovery would be ensured, if the humancaused disturbance resembled the natural one. However, the critical question is how similar are the ecological consequences of natural disturbance and human-caused disturbance and do they initiate similar secondary succession? Does the ecosystem recover towards a natural type of mature forest after humancaused disturbance?

Very few studies exist on the comparison between succession after clear-cutting and after natural disturbance. Halpern and Spies (1995) reported that changes in understory plant species richness in Pseudotsuga forests are fairly short-lived (a few years) following clear-cutting and slash burning, and populations of most vascular plants recovered to original levels prior to canopy closure. Halpern and Spies (1995) noted that floristically, 70-90\% of understory taxa survived logging and burning, and of the 10-30\% that initially disappeared, most eventually reappeared. However, a few species appeared to be eliminated by clear-cutting and/or slash burning. Unfortunately, Halpern and Spies (1995) were not able to compare the succession after forestry operations with that after natural disturbance.

Data sets from Finland indicate that plant community succession is different after clear-cutting and after forest fire, although the communities become increasingly similar to the mature forest as succession proceeds (Fig. 3, Aspi and Helle, 1984). The most obvious difference in recovery after clear-cutting and fire is right after the impact. Communities of vascular plants remained fairly similar to those in the mature forest a few years after clear-cutting, but decreased in similarity very rapidly as open habitat species increased and old-forest specialists disappeared. In contrast, right after a forest fire the vascular plant community resembles very little that of a mature forest community indicating that the immediate impact of fire is more severe than that of clear-cutting. The communities impacted by fire were less similar to the mature forest than were communities affected by cutting throughout the succession (Fig. 3). The similarity of plant communities between old regenerating sites and mature sites (>100 years) is only $50-70 \%$ suggesting that plant recovery is very slow and takes considerably more than 100 years.

In other taxa recovery studies are even scarcer. For instance, in some groups of predatory arthropods' 


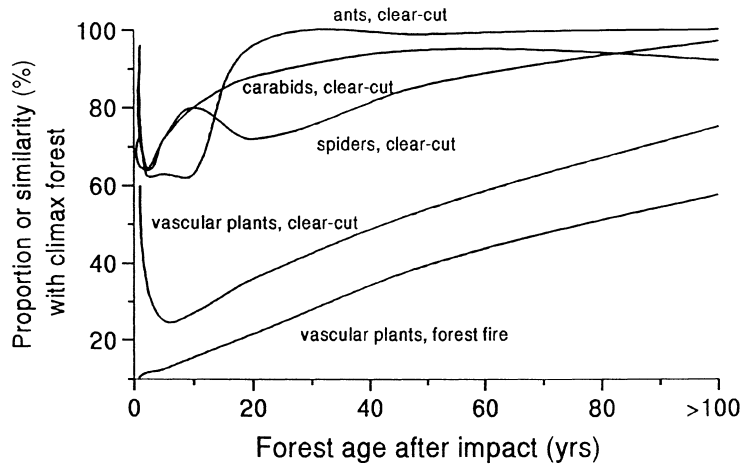

Fig. 3. Similarity of species composition of ants, carabids and spiders between old-growth and younger forest age classes calculated as a proportion of those species that occur in the younger forest age classes and in the old-growth classes $(>100$ years) (Niemelä et al., 1996). For vascular plants a percentage similarity index was used to compare the communities in the younger forest age classes with the old-growth classes (Aspi and Helle, 1984).

succession after clear-cutting shows that, as in plants, communities remain fairly similar to those in the mature forest a few years after clear-cutting, but decrease in similarity very rapidly as open habitat species increase and old-forest specialists disappear (Fig. 3; Niemelä et al., 1993, 1994). Recovery starts some 10-20 years after the impact and invertebrate communities in 60-80-year-old sites are quite similar to those in mature forests. Although populations of predatory arthropods seem to recover fairly rapidly after clear-cutting, some other taxa may not recover as easily. Økland (1994) noted that the fungus gnat communities (Mycetophilidae) of mature, managed forests (cut 70-120 years earlier) lacked many species occurring in the semi-natural forest (only selectively cut most recently ca. 60 years ago).

A crucial group of species to consider in the recovery process is that requiring old-growth forest and thus vulnerable to timber harvesting. The number of such species varies considerably among taxonomic groups according to studies listed in Table 1 . In predatory arthropods and small mammals, the proportion of oldgrowth specialists is less than $10 \%$, whereas about one-third of fungus gnats are restricted to old-growth forest. In amphibians and reptiles the proportion is less than $20 \%$, and in birds it ranges from 0 to $40 \%$ depending on the study area. In the understory vascular plants the proportion is less than $10 \%$, whereas in overstory plants the proportion is higher. In fungi, the old-growth specialists make up $10-20 \%$ of the forest dwellers. As many of these species inhabit a certain micro-habitat, their recovery can be enhanced

Table 1

The proportion and number of species found only in natural, old-growth forest in different groups of organisms and different studies

\begin{tabular}{|c|c|c|c|c|c|}
\hline \multirow[t]{2}{*}{ Taxon } & \multicolumn{2}{|c|}{ Old-growth taxa } & \multirow{2}{*}{$\begin{array}{l}\text { Total no. } \\
\text { species }\end{array}$} & \multirow[t]{2}{*}{ Study area } & \multirow[t]{2}{*}{ Reference } \\
\hline & $\%$ & No. & & & \\
\hline Ground beetles (Carabidae) & 2 & 1 & 56 & Finland & Niemelä et al., 1988 and unpubl. \\
\hline Ground beetles & 9 & 5 & 53 & Canada & Niemelä et al., 1993 and unpubl. \\
\hline Spiders (Araneae) & 5 & 6 & 127 & Finland & Pajunen, 1995 \\
\hline Amphibians and reptiles & $6-16$ & $1-4$ & $18-25$ & USA & Hansen et al., 1991 \\
\hline Small mammlas & $0-6$ & $0-1$ & $16-27$ & USA & Hansen et al., 1991 \\
\hline Birds & $0-40$ & $0-6$ & $15-46$ & USA & Hansen et al., 1991 \\
\hline Birds & 14 & 5 & 36 & Finland & Haila et al., 1994 \\
\hline Fungus gnats (Mycetophilidae) & 33 & 34 & 104 & Norway & Økland, 1994 \\
\hline All plants (excl. trees) & 5 & 6 & 125 & Finland & Paalamo, 1995a \\
\hline All plants (excl. trees) & $<1$ & 1 & 134 & Finland & Paalamo, 1995a \\
\hline Vascular plants (understory) & $3-8$ & $5-8$ & $98-173$ & USA & Hansen et al., 1991 \\
\hline Vascular plants (overstory) & $13-44$ & $2-4$ & $9-16$ & USA & Hansen et al., 1991 \\
\hline Wood-inhabiting fungi & 11 & 8 & 70 & Finland & Penttilä, 1991 \\
\hline Wood-inhabiting fungi & 16 & 8 & 49 & Finland & Penttilä, 1995 \\
\hline Fungi (mainly Agaricales) & 13 & 33 & 253 & Finland & Paalamo, 1995b \\
\hline Fungi (mainly Agaricales) & 8 & 19 & 227 & Finland & Paalamo, 1995b \\
\hline Fungi & 17 & 8 & 47 & USA & Hansen et al., 1991 \\
\hline
\end{tabular}


by the maintenance and re-creation of such habitat structures and by ensuring their spatial connectivity (Niemelä et al., 1993; Haila, 1994, 1995; Haila et al., 1994).

In addition to stand-level changes, landscape scale differences between natural disturbance and harvesting operations are clear. Forestry often creates a different mosaic of forest stands than do natural disturbances. For instance, Mladenoff et al. (1993) reported from study areas in Wisconsin that a number of important structural features of the intact oldgrowth landscape do not occur in the disturbed and fragmented landscape. The largely successional landscape fragmented by forestry had more forest-types, more small forest patches, while their shape was simpler than in the intact landscape. This resulted in lower connectivity and thus greater habitat isolation in the fragmented landscape as compared to the intact one (Mladenoff et al., 1993). Edenius and Elmberg (1996) reported from northern Sweden that forestry tends to be concentrated in areas with large contiguous forest tracts subdividing it into smaller units and accentuating the natural variation in the landscape. In Russian taiga, Syrjänen et al. (1994) found that forestry dramatically alters the landscape structure of a spruce forest.

These landscape-level changes, that is, forest fragmentation, affect communities. For instance, Väisänen et al. (1986) reported that bird species of the northern taiga that have generally declined in Finland have also declined in small tracts of virgin forest (tens of square kilometers), while Virkkala (1991) showed that in large tracts of intact forest (hundreds of square kilometers) the same species have not declined. Thus, it is important to leave large intact forest areas for the survival of old-growth specialists. However, the exact effects of landscape-level changes on other forest organisms than birds are poorly known but they can be expected to be significant (Niemelä et al., 1994). Thus, further research into landscape-level biotic changes following forestry is needed but also methods for landscape-level harvesting planning need to be developed.

\subsection{Population recovery and management}

I suggest that at the level of forest stands change in community structure, that is, secondary succession, be used as a measure of the effects of forest harvesting on boreal biota. In practice, it is necessary to use surrogate taxa instead of single species in research and monitoring of ecosystem resilience. A surrogate both indicates and represents the entities or characteristics it is used as a substitute for (Haila, 1995). As individual species are problematic as surrogates, it seems more promising to use groups of species. For instance, in Sweden, a method of using the amount of large trees and four taxa (woodpeckers, vascular plants, lichens and wood-living beetles) together has been proposed for assessing the conservation value of forests (Rundlöf and Nilsson, 1995). Population changes of these taxa could also be used in assessing the recovery of forest ecosystems after human-caused disturbance as compared to natural disturbance.

Development of timber harvesting methods should be directed to create favorable conditions for naturallike secondary succession. The methods should retain, and, if possible, increase the amount of 'micro-habitats,' especially coarse woody debris and deciduous trees that are important for many species but that have been removed from the managed forests during recent decades (Esseen et al., 1997). Furthermore, aberrant sites that do not easily recover should be left untouched when harvesting. Several such 'key habitats' have already been identified, for example, in the new Finnish forest legislation (Savolainen, 1997).

If forest recovery is to be secured, landscape-level planning of forestry is of vital importance. For instance, even if coarse woody debris is left and the right habitat is restored, it may be impossible for wood-living species to colonize, if source areas are too far apart. A useful guideline here is the natural configuration of forest-types and stands (Haila and Kouki, 1994). What is then the right patch size to be used for planning purposes? Haila et al. (1994) suggested that patch size of 5-50 ha corresponds to natural size distribution and could be used to guide management. However, they emphasized that sufficient representation of different forest-types and especially old age classes must be maintained at the landscape scale to ensure dispersal (see also Hansen et al., 1991).

In addition to the spatial scale, the temporal scale of forestry operations is important. Currently, the rotation time does not correspond well to the time of major 
natural disturbances (Haila and Kouki, 1994; Wallin et al., 1996). As a result, especially mesic-moist and wet stands have been harvested before they have reached a high enough age for structures necessary for the sensitive old-growth species to appear. Thus, the temporal scale of forestry operations should be adjusted to the natural disturbance regime of the particular forest-type and success of the modified forestry methods should be assessed by studying the recovery of the impacted ecosystem. Succession in boreal forest is slow but by selecting appropriate study organisms, such as invertebrates, preliminary guidelines for forestry may be obtained within a few years after the impact.

It is vital that the development of ecologically sound forest management methods proceeds in an iterative fashion together with increased ecological understanding of their effects (Haila, 1994, 1995; Franklin, 1995; Niemelä, 1997). Forestry methods need to be continuously refined as research provides information about their success or failure. Ecosystem recovery using population dynamics of surrogate taxa could form the basis for the evaluation of the ecological success of new timber harvesting methods.

\section{Acknowledgements}

I thank two anonymous referees for constructive comments, and the Academy of Finland for funding (project number 10134485).

\section{References}

Aarne, M. (Ed.), 1995. Statistical yearbook of forestry. Agriculture and Forestry 1995, 5. The Forest Statistics Information Service of the Finnish Forest Research Institute, Vantaa.

Angelstam, P., 1996. The ghost of forest past - Natural disturbance regimes as a basis for reconstruction of biologically diverse forests in Europe. In: DeGraaf, R.M., Miller, R.I. (Eds.), Conservation of Faunal Diversity in Forested Landscapes, Chapman and Hall, London, pp. 287-337.

Angelstam, P., Rosenberg, P., Rülcker, C., 1993. Aldrig, sällan, ibland, ofta (in Swedish). Skog och Forskning 1, 34-41.

Aspi, J., Helle, P., 1984. Ekologinen sukkessio (in Finnish, with English abstract). Luonnon Tutkija 88, 186-193.

Christensen, N.L., Bartuska, A.M., Brown, J.H., Carpenter, S., D'Antonio, C., Francis, R., Franklin, J.F., MacMahon, J.A., Noss, R.F., Parsons, D.J., Peterson, C.H., Turner, M.G.,
Woodmansee, R.G., 1996. The report of the Ecological Society of America committee on the scientific basis for ecosystem management. Ecol. Appl. 6, 665-691.

Edenius, L., Elmberg, J., 1996. Landscape level effects of modern forestry on bird communities in north Swedish boreal forests. Landscape Ecol. 11, 325-338.

Esseen, P.-A., Ehnström, B., Ericson, L., Sjöberg, K., 1997. Boreal forests. Ecol. Bull. 46, 16-47.

Fiedler, P.L., White, P.S., Leidy, R.A., 1997. The paradigm shift in ecology and its implications for conservation. In: Pickett, S.T.A., Ostfeld, R.S., Shachak, M., Likens, G.E. (Eds.), The Ecological Basis of Conservation: Heterogeneity, Ecosystems, and Biodiversity. Chapman and Hall, New York, pp. 83-92.

Franklin, J.F., 1995. Why link species conservation, environmental protection, and resource management? In: Jones, C.G., Lawton, J.H. (Eds.), Linking Species and Ecosystems. Chapman and Hall, New York, pp. 326-335.

Haila, Y., 1994. Preserving ecological diversity in boreal forests: Ecological background, research, and management. Ann. Zool. Fenn. 31, 203-217.

Haila, Y., 1995. Natural dynamics as a model for management: Is the analogue practicable? Arctic Centre Publications 7, 9-26.

Haila, Y., 1997. A 'natural' benchmark for ecosystem function. Conserv. Biol. 11, 300-301.

Haila, Y., Kouki, J., 1994. The phenomenon of biodiversity in conservation biology. Ann. Zool. Fenn. 31, 5-18.

Haila, Y., Hanski, I.K., Niemelä, J., Punttila, P., Raivio, S., Tukia, H., 1994. Forestry and boreal fauna: Matching management with natural forest dynamics. Ann. Zool. Fenn. 31, 187-202.

Hallman, E., Hokkanen, M., Juntunen, H., Korhonen, K.-M., Raivio, S., Savela, O. Siitonen, P., Tolonen, A., Vainio, M., 1996. Alue-ekologinen suunnittelu (in Finnish). Metsähallituksen metsätalouden, 3, julkaisuja Metsähallitus, Vantaa, 55 pp.

Halpern, C.B., Spies, T.A., 1995. Plant species diversity in natural and managed forests of the Pacific Northwest. Ecol. Appl. 5, 913-934.

Hansen, A.J., Spies, T.A., Swanson, F.J., Ohmann, J.L., 1991. Conserving biodiversity in managed forests. BioScience 41 , 382-392.

Holling, C.S., 1992. The role of forest insects in structuring the boreal landscape. In: Shugart, H.H., Leemans, R., Bonan, G.B. (Eds.), A Systems Analysis of the Global Boreal Forest. Cambridge University Press, Cambridge, pp. 170-191.

Holling, C.S., 1996. Surprise for science, resilience for ecosystems, and incentives for people. Ecol. Appl. 6, 733-735.

Hunter, M., 1993. Natural fire regimes as spatial models for managing boreal forests. Biol. Conserv. 65, 115-120.

Loope, W.L., 1991. Interrelationship of fire history, land-use history, and landscape pattern within Pictured Rocks National Lakeshore. Michigan Can. Field-Nat. 105, 18-28.

Mladenoff, D.J., White, M.A., Pastor, J., Crow, T.R., 1993. Comparing spatial pattern in unaltered old-growth and disturbed forest landscapes. Ecol. Appl. 3, 294-306.

Niemelä, J., 1997. Invertebrates and boreal forest management. Conserv. Biol. 11, 601-610.

Niemelä, J., Haila, Y., Halme, E., Lahti, T., Pajunen, T., Punttila, P., 1988. The distribution of carabid beetles in fragments of old 
coniferous taiga and adjacent managed forest. Ann. Zool. Fenn. $25,107-119$.

Niemelä, J., Langor, D., Spence, J.R., 1993. Effects of clear-cut harvesting on boreal ground-beetle assemblages (Coleoptera: Carabidae) in western Canada. Conserv. Biol. 7, 551-561.

Niemelä, J., Spence, J.R., Langor, D., Haila, Y., Tukia, H., 1994. Logging and boreal ground-beetle assemblages on two continents: Implications for conservation. In: Gaston, K., Samways, M., New, T. (Eds.), Perspectives in Insect Conservation. Intercept, Andover, pp. 29-50.

Niemelä, J., Haila, Y., Punttila, P., 1996. The importance of smallscale heterogeneity in boreal forests: Diversity variation in forest-floor invertebrates across the successional gradient. Ecography 19, 352-368.

Noss, R.F., Cooperrider, A.Y., 1994. Saving Nature's Legacy. Protecting and Restoring Biodiversity. Island Press, Washington, DC.

Økland, B., 1994. Mycetophilidae (Diptera), an insect group vulnerable to forestry practices? A comparison of clearcut, managed and semi-natural spruce forests in southern Norway. Biodivers. Conserv. 3, 68-85.

Paalamo, P., 1995a. Pintakasvillisuuden lajimäärät. In: Raivio, S. (Ed.), Talousmetsien luonnonsuojelu-yhteistutkimushankkeen väliraportti (in Finnish), Metsähallituksen luonnonsuojelujulkaisuja, sarja A:43, Vantaa, pp. 48-53.

Paalamo, P., 1995b. Sienilajisto. In: Raivio, S. (Ed.), Talousmetsien luonnonsuojelu-yhteistutkimushankkeen väliraportti (in Finnish). Metsähallituksen luonnonsuojelujulkaisuja, sarja A:43, Vantaa, pp. 54-63.

Penttilä, R., 1991. Kääpälajiston esiintyminen käsittelytavoiltaan erilaisissa metsissä Keski-Suomessa (in Finnish). Master of Science thesis, Department of Ecology and Systematics, University of Helsinki.

Penttilä, R., 1995. Käävät. In: Raivio, S. (Ed.), Talousmetsien luonnonsuojelu-yhteistutkimushankkeen väliraportti (in Finnish). Metsähallituksen luonnonsuojelujulkaisuja, sarja A:43, Vantaa, pp. 64-73.

Perry, D.A., Amaranthus, M.P., 1997. Disturbance, recovery, and stability. In: Kohm, K.A., Franklin, J.F. (Eds.), Creating a Forestry for the 21st Century: The Science of Ecosystem Management. Island Press, Washington DC, pp. 31-56.

Pickett, S.T.A., Parker, V.T., Fiedler, P.L., 1992. The new paradigm in ecology: Implications for conservation biology above the species level. In: Fiedler, P.L., Jain, S.K. (Eds.), Conservation Biology: The Theory and Practice of Nature Conservation, Preservation, and Management. Chapman and Hall, New York, pp. $65-88$.

Pajunen, T., 1995. Hämähäkkilajisto metsäsukkessiossa. In: Raivio, S. (Ed.), Talousmetsien luonnonsuojelu-yhteistutkimushankk- een väliraportti (in Finnish). Metsähallituksen luonnonsuojelujulkaisuja, sarja A:43, Vantaa, pp. 97-102.

Pimm, S.L., 1991. The Balance of Nature? University of Chicago Press, Chicago.

Rassi, P., Kaipiainen, H., Mannerkoski, I., Ståhls, G., 1991. Uhanalaisten eläinten ja kasvien seurantatoimikunnan mietintö (Report on the monitoring of threatened animals and plants in Finland, (in Finnish with English abstract). Committee report 1991:30, Ministry of Environment, Helsinki.

Rundlöf, U., Nilsson, S.G., 1995. Fem Ess metoden: spåra skyddsvärd skog i södra Sverige (in Swedish). Naturskyddsföreningen, Helsingborg.

Savolainen, J. (Ed.), 1997. Metsälaki perusteluineen (in Finnish). Edita, Helsinki.

Siitonen, J., Martikainen, P., 1994. Occurrence of rare and threatened insects living on decaying Populus tremula: A comparison between Finnish and Russian Karelia. Scand. J. For. Res. 9, 185-191.

Sprugel, D.G., 1991. Disturbance, equilibrium, and environmental variability: What is 'natural' vegetation in a changing environment? Biol. Conserv. 58, 1-18.

Syrjänen, K., Kalliola, R., Puolasmaa, A., Mattsson, J., 1994. Landscape structure and forest dynamics in subcontinental Russian European taiga. Ann. Zool. Fenn. 31, 19-34.

Urban, D.L., O’Neill, R.V., Shugart, H.H., 1987. Landscape ecology: A hierarchical perspective can help scientists understand spatial patterns. BioScience 37, 119-127.

Virkkala, R., 1991. Population trends of forest birds in Finnish Lapland in a landscape of large habitat blocks: Consequences of stochastic environmental variation or regional habitat alteration? Biol. Conserv. 56, 223-240.

Väisänen, R.A., Järvinen, O., Rauhala, P., 1986. How are extensive, human-caused habitat alterations expressed on the scale of local populations in boreal forests? Ornis Scand. 17, 282-292.

Wallin, D.O., Swanson, F.J., Marks, B., Cissel, J.H., Kertis, J., 1996. Comparison of managed and pre-settlement landscape dynamics in forests of the Pacific Northwest, USA. For. Ecol. Manag. 85, 291-309.

Wiens, J.A., 1997. The emerging role of patchiness on conservation biology. In: Pickett, S.T.A., Ostfeld, R.S., Shachak, M., Likens, G.E. (Eds.), The Ecological Basis of Conservation: Heterogeneity, Ecosystems, and Biodiversity. Chapman and Hall, New York, pp. 93-107.

Wikars, L.-O., 1992. Skogsbränder och insekter (Forest fires and insects, in Swedish with English abstract). Entomol. tidskr. 113, $1-11$.

Wu, J., Loucks, O.L., 1995. From balance of nature to hierarchical patch dynamics: A paradigm shift in ecology. Q. Rev. Biol. 70, 439-466. 